\title{
DEPOSITION OF METAL FILMS ON MICROPARTICLES TRAPPED IN RF MAGNETRON DISCHARGE
}

\author{
A.F. PAL, A.G. RUDAVETS, A.N. RYABINKIN, A.O. SEROV
}

PACS 52.27.Lw; 52.77.-j

(C) 2011

Institute of Nuclear Physics, Lomonosov Moscow State University

(1(2), Leninskie gory, GSP-1, Moscow 119991, Russian Federation)

The technique for a metal film deposition on spherical microparticles in an RF plasma trap is presented. Both the particle confinement and the electrode sputtering are performed by a single RF magnetron discharge. The samples of a coated spheres are obtained and examined. The technique allows confining the particles near to the sputtered region close to the border zone of ballistic bombardment by sputtered atoms.

\section{Introduction}

Metal-coated spherical particles have a range of applications and are used in the signal processing and in the photovoltaic units. Macroscopic number of microspheres can be packed (by condensation or centrifugation techniques) in a 2- or 3D crystal or a slightly ordered (super)lattice with the further annealing for hardening. Such materials possess the unique optical properties of photonic crystals due to a periodic variation of the refractive index.

There are a few techniques based on the magnetron sputtering to deposit a metal film on spherical microparticles, whose sizes are greater than $5 \mu \mathrm{m}[1-3]$, and only one was developed for smaller particles [4]. The main feature of the latter is confining the treated microparticles in a dusty plasma trap. In plasma, the microparticles gain large negative charges that block their agglomeration.

The final state of a film depends on the energy of atoms forming a coating. At thermal energy, the arrived atoms only randomly stick to the surface. But, at the higher energy of sputtered atoms, they can diffuse over the interface climbing up and down heights and filling valleys, which decreases the surface roughness. This necessitates bringing the atom source to microparticles closer than the thermalization length in order to coat them with "hot" atoms. The scheme of our coating technique ensures the implementation of this recipe.

\section{Experiment}

The microparticles are confined in a trap formed in the RF magnetron discharge plasma (Fig. 1). The magnetron discharge is characterized by the essentially nonuniform plasma density along the negatively biased electrode. The density distribution has a maximum in a narrow ring-shaped zone near to the electrode [5] so that, at the borders of the zone, the electric fields, which are directed outward, exist. The fields form a trap for negatively charged particles. Just below this zone, the ions bombard the electrode closely to particles at a distance, which is of the order of the sheath thickness. The electrode surface is sputtered here, and an atomic beam arises to form the coating on the particles in the trap.

Copper or silver grounded plane target was mounted on the bottom of a cylindrical vacuum chamber. Linear magnetron magnetic system (1), forming the arcshaped magnetic field in the discharge region, is placed under grounded electrode (2). The magnetic induction was about of $0.05 \mathrm{~T}$ at a height of $2 \mathrm{~mm}$ above the target surface in the region, where the magnetic field lines are parallel to the surface. The capacitive RF discharge of $5 \mathrm{MHz}$ in argon gas in the pressure interval 6-13 $\mathrm{Pa}$ with the flow up to 2 sccm was used. The discharge plasma looks from the top like an elongated glowing ring. The discharge peak-to-peak voltage was up to

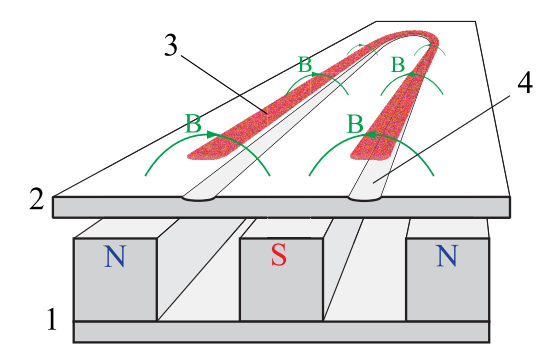

Fig. 1. Schematic diagram of the electrode assembly for the deposition of a metal film on microparticles (cross-section): magnetic system (1), sputtered electrode (2), trapped particles (3), sputtered area (4) 


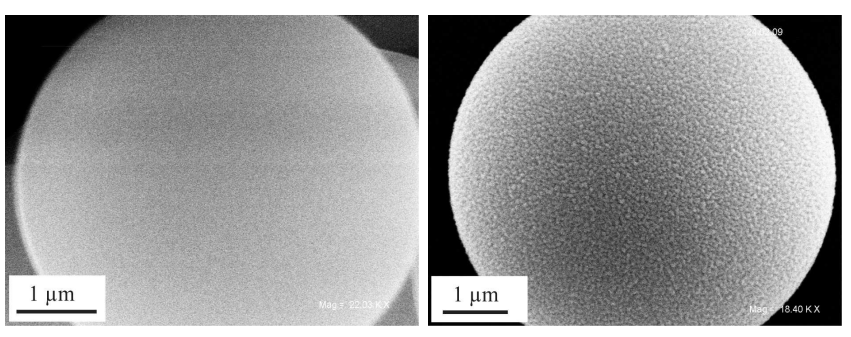

Fig. 2. Original (left) and coated by silver (right) silica particles

$380 \mathrm{~V}$. The positive self-bias of the powered electrode was up to $70 \mathrm{~V}$. The closed contour of the sputtered area was $185 \mathrm{~mm}$ in length and $23 \mathrm{~mm}$ in width. To inject particles into the plasma, the additional DC discharge was used. The glassy carbon powders consisting of balls with diameters in the intervals of $0.4-12,8-26$, and $15-$ $32 \mu \mathrm{m}$ and monodisperse silica particles of $5.35 \mu \mathrm{m}$ diameter were used. The levitating cloud was visualized by the laser light scattering technique. The top view of cloud (3) in our experiment was geometrically similar to the form of sputtered track (4). The deposition time was varied from 5 to $15 \mathrm{~min}$. The coated microspheres were collected on the special substrate placed near to the sputtered area at the side opposite to the injecting electrode. By shifting the magnetic system and inclining the chamber, one can locate the trap with microspheres above the substrate. The substrate has been covered by a movable screen that shielded it from the undesired untimely collection of microspheres and from the sputtered atom deposition. At the end of the each treatment, the screen was removed, the trap was shifted to the drain region, the $\mathrm{RF}$ voltage was turned-off, and the coated microspheres were collected on the substrate.

\section{Results and Discussion}

The confined particles form a ring-shaped cloud, whose distance from the electrode depends mainly on the kind of particles and slightly on the gas pressure value under the conditions of the experiment. During the deposition at a gas pressure of $13 \mathrm{~Pa}$, the lower border of the cloud was at the distance of $2 \mathrm{~mm}$ from the sputtered area for silica particles and at $1 \mathrm{~mm}$ for large glassy carbon ones. The vertical size of the cloud was approximately of $1 \mathrm{~mm}$. About $10^{5}$ particles are collected on the substrate at the end of each treatment. The SEM images of the substrates show that almost all the particles are separated from one another. Under the deposition process conditions, the agglomeration of trapped particles in the plasma was blocked.
The images obtained by an optical microscope show that the particles gain a metallic luster after the coating process longer than $10 \mathrm{~min}$. In addition, the $\mathrm{Cu}$ coated particles gain the characteristic color. SEM-EDS spectra obtained from the coated particles indicate that the films on particles consist of silver or partially oxidized copper. The typical SEM images of individual silica particles (original and coated with silver) are shown in Fig. 2. The surface of thin films obtained at a deposition time of 5-15 min has a roughness of few nanometers for almost all examined particles. The majority of copper thin films have a surface roughness which is lower than that of silver ones. In both cases, the film surface was uniform for the deposition time. The trapped particles drift along the trap contour [6] in the direction of the circulating magnetron electron drift $[5,7]$, and each particle can perform the spin motion $[8,9]$, which provides the same deposition conditions for them and the film uniformity.

The films on silica particles having a smooth surface before the deposition never demonstrated the detachment. To determine the average film growth rate on silica balls, we broke them in some parts and estimated the film thickness using the SEM images of disruptions of the film. The corresponding growth rate was about $10^{-1} \mathrm{~nm} / \mathrm{s}$.

Since the inelastic scattering in the inert buffer gas is marginal due to a small cross section, the slowing down of sputtered atoms occurs due to elastic collisions in the buffer gas. To estimate the energy of atoms forming the film in our experiments, we analyzed the sputtered atom slowing down occurring due to elastic collisions in a buffer gas, which characterized by the mean free path $\lambda=1 / n \sigma$, where $n$ is the gas number density, and $\sigma$ is the scattering cross-section. For the hardsphere (HS) collision model valid at high-energy collisions, $\sigma_{\mathrm{HS}}=\pi\left(r_{1}+r_{2}\right)^{2}$, where $r_{1}, r_{2}$ are effective atom radii usually derived from quantum calculations. However, in fact, the corresponding $\lambda_{\mathrm{HS}}$ sets only a crude estimate, because, for the typical atomic energy (which usually does not exceed $50 \mathrm{eV}$ in the magnetron sputtering), the long-range van der Waals (vdW) force comes into play to be responsible for the mean free path $\lambda_{\mathrm{vdW}}$ be an order less than $\lambda_{\mathrm{HS}}$. The stopping power of vdW collisions on a travel distance $d x$ is governed by the equation

$\frac{d E}{d x}=\int_{0}^{\infty} T\left(E_{1}, E_{2}\right) \sigma_{\mathrm{vdW}} n\left(E_{2}\right) d E_{2}$ 
where $E_{1}, E_{2}$ are the energies of "hot" and "cold" atoms, $T\left(E_{1}, E_{2}\right)$ is the energy loss of a sputtered atom in binary collisions with "cold" atoms of the buffer gas having the Maxwellian energy distribution (in case of $E_{1} \gg E_{2}$, $T\left(E_{1}, E_{2}\right) \approx-0.5 \gamma E_{1}$, where $\gamma=4 m_{1} m_{2} /\left(m_{1}+m_{2}\right)^{2}$, and $m_{1}, m_{2}$ are masses of sputtered and buffer gas atoms, correspondingly), $\int_{0}^{\infty} n\left(E_{2}\right) d E_{2}=n$, where $n$ is the buffer gas number density, $\sigma_{\mathrm{vdW}} \approx 8 C_{6} /(\hbar v)^{2 / 5}[10]$, where $v$ is the relative velocity of atoms, $\hbar$ is the reduced Planck constant, $C_{6}=\frac{3}{2} \alpha_{1}^{A} \alpha_{1}^{B} I_{1}^{A} I_{1}^{B} /\left(I_{1}^{A}+I_{1}^{B}\right)$ [11], where $\overline{\alpha_{1}^{A}}, \overline{\alpha_{1}^{B}}$ are the average dipole dynamic polarizabilities of $A$ and $B$ atoms, $I_{1}^{A}, I_{1}^{B}$ are their ionization potentials.

The energy loss of sputtered Ag atoms in Ar was obtained by solving Eq. (1). The characteristic energy of sputtered atoms under the conditions of our experiment estimated according to Stepanova et al. [12] was about $10 \mathrm{eV}$. The gas pressure value was taken to be $13.3 \mathrm{~Pa}$. It was found that the thermal equilibrium is reached on the path of about $1.5 \mathrm{~mm}$. This value is inside the range of the distances from the confined particles to the target in our deposition experiment. The more precise estimation of the thermalization length should be found experimentally, as well as the dependence of the film structure on the sputtered atom travel distance should be investigated in more details.

\section{Conclusions}

We have developed the technique of film deposition by sputtered atoms on spherical microparticles trapped in plasma near the ballistic bombardment zone, when both confining the microparticles and sputtering the target were performed by a single RF discharge. The films were uniformly deposited over the whole surface of spherical microparticles with a deposition rate of about $10^{-1} \mathrm{~nm} / \mathrm{s}$. The obtained samples of coated spherical microparticles have a film thickness of about $50 \mathrm{~nm}$, and the film roughness is about a few $\mathrm{nm}$.

This work was partly supported by RFBR project \# 08-02-01212-a and INTAS project \# 06-1000013-9427.
1. S.F. Meyer, E.J. Hsieh, and R.J. Burt, Thin Solid Films 72, 373 (1980).

2. C. Chujiang, Y. Xiaozheng, S. Zhigang et al., J. of Phys. D: Appl. Phys. 40, 6026 (2007).

3. A. Taguchia, M. Inouea, C. Hiromia et al., Vacuum 83, 575 (2008).

4. H. Kersten, R. Wiese, G. Thieme et al., New J. of Phys. 5, 93.1 (2003).

5. H. Kakati, A.R. Pal, H. Bailung et al., J. of Phys. D: Appl. Phys. 40, 6865 (2007).

6. A.F. Pal, A.O. Serov, A.N. Starostin et al., in 18th Europhysics Conference on the Atomic and Molecular Physics of Ionized Gases (Lecce, Italy, 2006), p. 203.

7. S.M. Rossnagel and H.R. Kaufman, J. of Vacuum Sci. Techn. A 5, 88 (1987).

8. V.N. Tsytovich, N. Sato, and G.E. Morfill, New J. of Phys. 5, 43.1 (2003).

9. I.H. Hutchinson, New J. of Phys. 6, 43 (2004).

10. Handbook of Atomic, Molecular, and Optical Physics, edited by G.W.F. Drake (Springer, Berlin, 2006).

11. I.G. Kaplan, Intermolecular Interactions: Physical Picture, Computational Methods and Model Potentials (Wiley, New York, 2006).

12. M. Stepanova and S.K. Dew, J. of Vacuum Sci. Techn. A 19, 2805 (2001).

Received 20.10.10

ОСАДЖЕННЯ МЕТАЛІЧНИХ ПЛІВОК НА МІКРОЧАСТИНКИ У ПАСТЦІ ВЧ МАГНЕТРОННОГО РОЗРЯДУ

О.Ф. Паль, О.Г. Рудавець, О.М. Рябінкін, О.О. Серов

Р ез ю м е

Подано спосіб осадження плівок на сферичні мікрочастинки в плазмово-пиловій пастці. Магнетронний ВЧ розряд використовували як для утримання частинок, так i для розпилення електродів. Отримано і досліджено зразки сферичних частинок з металічним покриттям. Ця техніка дозволяє утримувати частинки поблизу межі області балістичного бомбардування розпорошеними атомами. 